\title{
The qualitative and quantitative assessment of the renal cortex of the clinically healthy rabbits
}

\author{
Ömer Gürkan DILEKK ${ }^{1, a, ®}$, Hasan ERDEN ${ }^{2, b}$, Erkut TURAN ${ }^{2, c}$, Rosen DIMITROV $^{3, d}$, \\ Kamelia STAMATOVA-YOVCHEVA, ${ }^{3, e}$, Emine KARAKURUM ${ }^{1, f}$
}

\begin{abstract}
${ }^{1}$ Burdur Mehmet Akif Ersoy University, Faculty of Veterinary Medicine, Department of Anatomy, Burdur, Turkey; ${ }^{2}$ Adnan Menderes University, Faculty of Veterinary Medicine, Department of Anatomy, Aydın, Turkey; ${ }^{3}$ Trakia University, Faculty of Veterinary Medicine, Department of Veterinary Anatomy, Histology and Embryology, Stara Zagora, Bulgaria. aOORID: 0000-0002-5717-3928; ' ORCID: 0000-0002-6470-0220; ' ORCID: 0000-0003-4037-8297;

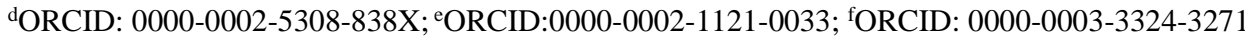

Corresponding author: ogdilek@gmail.com

Received date: 06.11.2019 - Accepted date: 17.03.2020

\begin{abstract}
Qualitative ultrasonographic images in diagnosing renal parenchymal diseases can be inadequate. The relationship between renal cortical echogenicity and parenchymal disease has been demonstrated in people. However, it is difficult to determine diffuse fat vacuoles and the parenchymal diseases at qualitative renal assessment. Disorders of the renal cortex are frequently seen in rabbits. The aim of this study was to qualitatively and quantitatively evaluate the echogenicity of the renal cortex in clinically healthy rabbits. Fourty-two clinically normal and with no history of renal disease rabbits were used. The each rabbit was investigated by complete blood count, urinalysis and renal biopsy. Renal ultrasonography was performed with a $6.5 \mathrm{MHz}$ probe. For each image, three equally sized regions of interest was detected within the renal cortex. The mean pixel intensity was determined using an 8-bit grayscale, with 256 colour of grey colours. Qualitative echogenicity was evaluated by two observers. Observer 1 evaluated as an isoechoic (36/42) and hyperechoic (6/42). Observer 2 evaluated as an isoechoic (35/42) and hyperechoic (7/42). Quantitatively, the mean pixel intensities analysed for the renal cortex was 59.2 \pm 2.23 (range: 28-91). The result of this study indicates that analysis of digitized renal cortical ultrasonographic images from rabbits using the histogram technique can be used to quantitatively determine echogenicity.
\end{abstract}

Keywords: Echogenicity, histogram, mean pixel intensity, rabbit, ren

\section{Klinik olarak sağlıklı tavşanlarda cortex renalis’in kalitatif ve kantitatif değerlendirilmesi}

Özet: Kalitatif ultrasonografik görüntüler, böbrek paranşimi hastalıklarının teşhisinde yetersiz kalabilmektedir. İnsanlarda böbreğin cortex renalis ekojenitesi ve paranşimal doku hastalıkları arasında bir ilişki olduğu kanıtlanmıştır. Bununla birlikte kalitatif renal ultrason muayenesinde diffüz yağ vakuolleri ile paranşimal hastalıkların teşhisi mümkün olamamaktadır. Yeni Zelanda tavşanları, özellikle anatomik ve fizyolojik deneylerde kullanılabilecek kadar küçük ve nispeten kolay erişilebildikleri için önemli bir modeldir. Tavşanlarda cortex renalis'e ilişkin hastalıklar sıklıkla görülmektedir. Bu çalışmanın amacı klinik olarak sağlıklı tavşanlarda cortex renalis'in kalitatif ve kantitatif analizinin yapılmasıdır. Çalışmada klinik olarak sağlıklı ve öyküsünde herhangi bir böbrek hastalığı bulunmayan kırk iki adet sağlıklı tavşan kullanıldı. Her bir tavşana kan sayımı, idrar fonksiyon testi ve renal biyopsi yapıldı. Renal ultrasonografi $6.5 \mathrm{MHz}$ prob kullanılarak uygulandı. Tüm görüntülerde cortex renalis bölgesinde üç adet odak noktası şekli oluşturuldu. Ortalama piksel yoğunluğu 8-bit 256 renkli gri-skala kullanılarak ölçüldü. Kalitatif ekojenite iki gözlemci tarafindan değerlendirildi. Gözlemci 1 izoekoik (36/42) ve hiperekoik (6/42) olarak değerlendirdi. Gözlemci 2 izoekoik (35/42) ve (7/42) olarak değerlendirdi. Kantitatif olarak cortex renalis ortalama piksel yoğunluğu 59.2 \pm 2.23 (min-maks: 28-91) olarak tespit edildi. Bu çalışmanın sonuçları, tavşanlarda cortex renalis'in ultrasonografik görüntülerinin histogram tekniği kullanılarak sayısal karakterize edilmesiyle kantitatif olarak kullanılabilecektir.

Anahtar sözcükler: Böbrek, ekojenite, histogram, ortalama piksel yoğunluğu, tavşan

\section{Introduction}

Due to its capacity to provide information about echogenicity, size and shape, ultrasonography is considered a useful tool for the diagnosis and assessment of kidney diseases in rabbits and other animals $(7,16,23)$.
The qualitative detection of diffuse fat vacuoles may be problematic in the kidney (7). Further, the detection of alterations in echogenicity is difficult in diffusely affected organs when compared to the situation in focally affected organs, since focal abnormalities stand out from the 
uniform background of the parenchyma, which has a normal ultrasonographic appearance (6). An organ's echogenicity is subjectively evaluated by means of the visual detection of that organ's brightness. Humans are not considered to be good assessors of echogenicity (19), since the human naked eye can only discriminate 10-12 shades of grey and 256 colours (20).

The histogram displays the tonal distribution of the image. In which values based on their level of brightness, on the $\mathrm{x}$ axis from dark (0) to light (255). The $\mathrm{y}$ axis represents the total number of pixels in the image with that level of brightness (1). Quantitative ultrasonography derives numerical values from the echogenicity data related to the mechanical properties of the tissue being evaluated. These numerical values enhance the accuracy in terms of differentiating between tissues with normal and abnormal ultrasonographic appearances (3, 21). Additionally, the presence of a plentiful amount of fat vacuoles in the renal cortex is positively associated with a large difference in echogenicity (25).

Fat vacuoles on renal cortex, aminoglycosideinduced nephrotoxicity, multiple renal cysts, hydronephrosis, glomerulosclerosis, glomerular crescents, tubular, interstitial fibrosis urolithiasis, hypercalciuria, are frequently seen in rabbits (16). The main aim of the present study was to qualitatively and quantitatively examine the echogenicity of the renal cortex in clinically healthy New Zealand rabbits.

\section{Material and Methods}

Animal and protocol: The study was approved by the Ethics Commission of the Mehmet Akif Ersoy University (Approval number: 93773921-1949-72). Forty-two New Zealand rabbits (9 months-old, weighing $4526 \pm 263.15$ g) 22 males, 20 females were used in this study. The rabbits were all determined to have no history of renal disease and their initial condition was investigated by means of a physical examination, blood count; Haemoglobin (HGB), haematocrit (HCT), mean corpuscular haemoglobin $(\mathrm{MCH})$, mean corpuscular haemoglobin concentration (MCHC), red blood cell (RBC), mean corpuscular volume (MCV), urinalysis, including $\mathrm{pH}$, urine volume, specific gravity, glucose, blood and urobilinogen. Rabbits were placed under sedation using $1 \mathrm{mg} / \mathrm{kg}$ of midazolam (Dormicum ${ }^{\circledR}$, Roche Hellas S.A. Alamanas, Greece). After sedation, each rabbit was placed in a dorsal recumbent position for the duration of the ultrasound examination. The rabbits' hair was clipped and acoustic gel was applied to the skin.

Ultrasound and histogram: The ultrasound examination was performed using a commercially available digital abdominal ultrasound platform equipped with a $6.5 \mathrm{MHz}$ short-focal-length micro-convex transducer (DC 6-Vet ${ }^{\circledR}$ Mindray Bio-Medical Electronics, Shenzhen, China). The ultrasound settings were; Gain 86 decibel $(\mathrm{dB})$, frame rate 78 frame per second (fps), dynamic range 65 decibel $\mathrm{dB}$, depth 6.2 millimeter $(\mathrm{mm})$. The rabbits were restrained in a left dorsal recumbent position during the ultrasonographic evaluation. The ultrasonographic echogenicity was evaluated qualitatively by two observers, namely a specialist in anatomy (observer 1) and a specialist in diagnostic imaging (observer 2). The rabbits' kidneys were anatomically evaluated for ultrasonographic anomalies. The images were analysed using the digital image analysis software Image $\mathrm{J}$ (1.46 r, NIH, USA).

For each image, three equally sized regions of interest were detected within the renal cortex. The mean pixel intensity within each regions of interest (ROI) was determined (Figure 1). A minimum of 400 pixels (20x20)

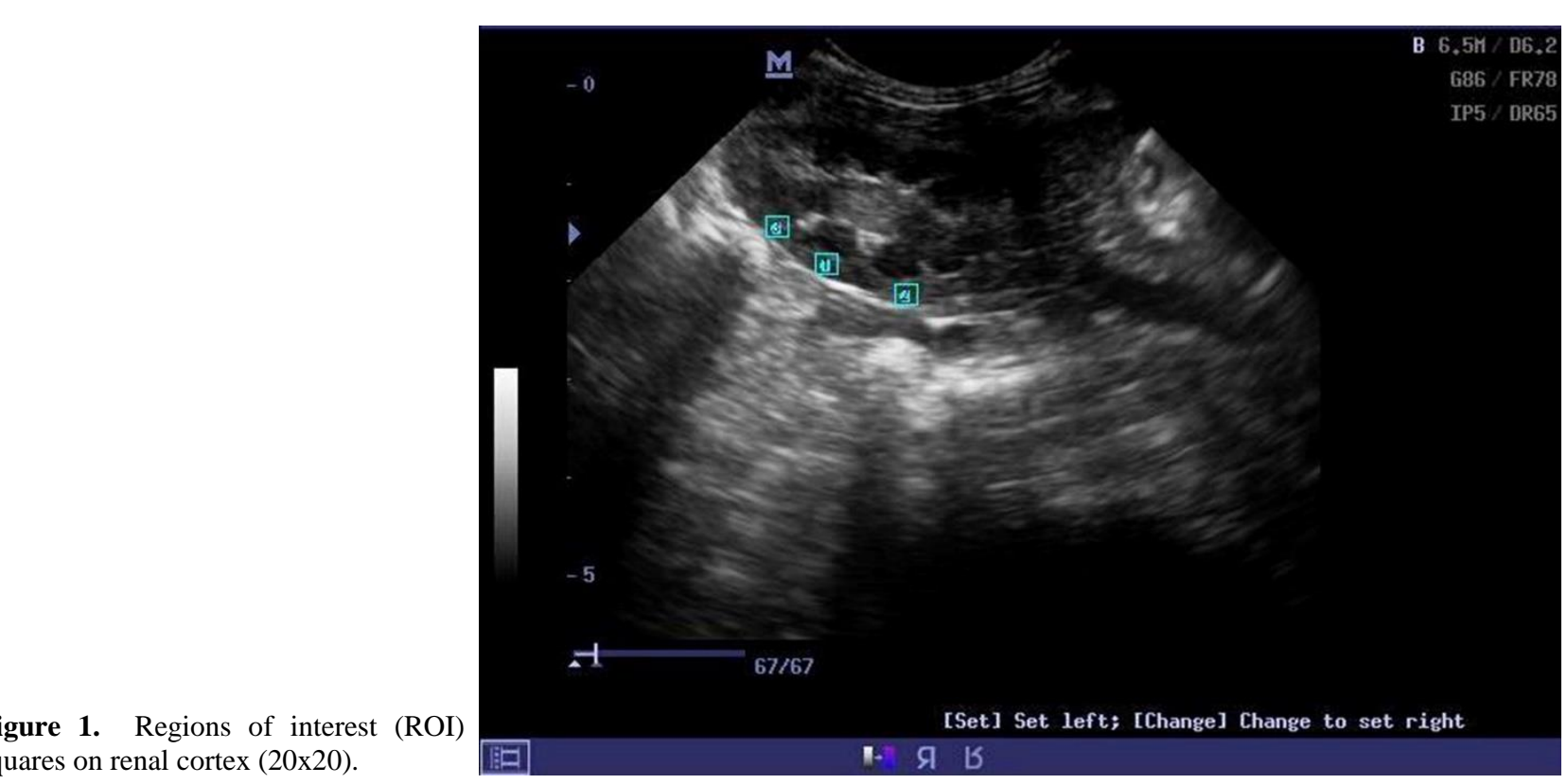
squares on renal cortex $(20 \times 20)$. 
were considered in each ROI (6). The mean pixel intensity was determined using an 8-bit grayscale, with 256 shades of grey (14) (Figure 2). In grey scale histogram schemes, the minimum grey level was zero. The maximum grey level depends on the digitisation depth of the image. For an 8-bit-deep image it is 255 . In a binary image a pixel can only take on either the value 0 or the value 255 . In contrast, in a greyscale or colour image a pixel can take on any value between 0 and 255. A grey level histogram indicates how many pixels of an image share the same grey level. The $\mathrm{x}$-axis shows the grey levels and the $y$-axis shows their frequency in the image. This information can be used to calculate a threshold (1). The mean, standard deviation and 95\% confidence interval (CI) of the data were calculated using SPSS software, version 19.0, for Windows (SPSS Inc. Chicago, IL, USA).

Biopsy and histology: The skin of the right paralumbar fossa was aseptically prepared. One centimeter skin incision was made using a number 4 blade
(Kai Europe Gmbh, Solingen, Germany). Four millimeter diameter biopsy punch was introduced into the skin hole and was advanced into the cranial pole of the kidneys, using ultrasonographic guidance. Tissues were removed and fixed in a $10 \%$ buffered formalin solution for 24 hours. After fixation, tissues were passed through graded alcohols and xylol and embedded in paraffin. Approximately, 3-5 $\mu \mathrm{m}$ thick sections were taken from tissues blocks with microtome and were stained with hematoxylin-eosin. Sections were examined under light microscope (Olympus BX 41).

\section{Results}

In this study, the renal cortex was evaluated both qualitatively and quantitatively in 42 clinically healthy New Zealand rabbits. All the blood count results including HGB, HCT, MCH, MCHC. RBC, MCV were within reference range limits (Table 1). No abnormality was detected in the renal cortex during the histological examination for any of the rabbits (Figure 3). The urinalysis

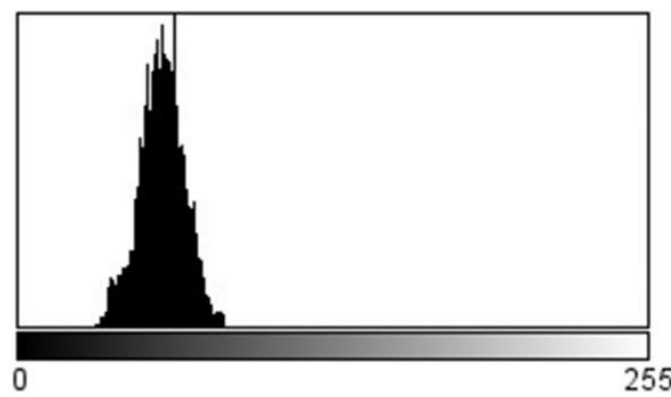

Count: 5346

Mean: 57.876

Min: 30

StdDev: 9.269

Mode: 63 (259)

Figure 3. Glomerules and tubules in the renal cortex (H\&E, x200). Arrow: Glomerulus, arrow head: Tubulus renalis.

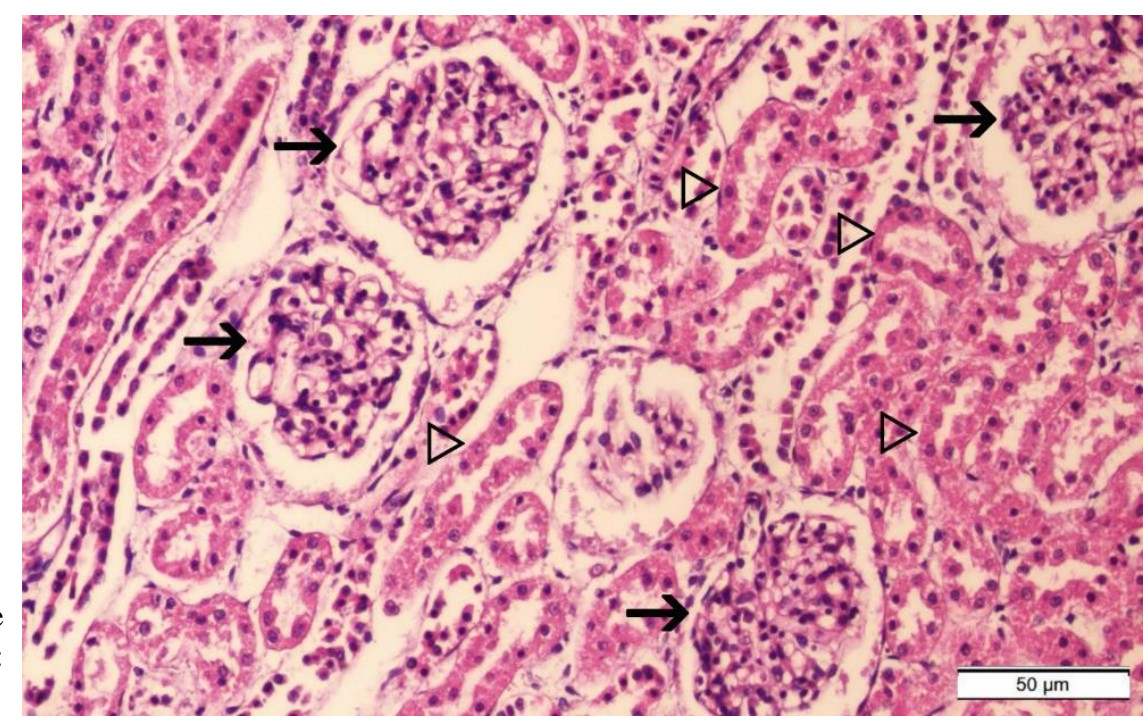


Table 1. Blood count results.

\begin{tabular}{ccccccc}
\hline Parameter & HGB & HCT & MCH & MCHC & RBC & MCV \\
g/dl & fo & pg & fld & 10 $/ \mathbf{l}$ & (n) \\
\hline Rabbits (n: 42) & $14.11 \pm 1.15$ & $45.99 \pm 4.5$ & $17.68 \pm 2.07$ & $32.4 \pm 4.95$ & $7.9 \pm 0.82$ & $65.25 \pm 3.82$ \\
\hline
\end{tabular}

Values were shown as a mean \pm standard deviation.

Table 2. Urinalysis results of 42 clinically healthy rabbits.

\begin{tabular}{cccclcc}
\hline Parameter & $\mathbf{p H}$ & $\begin{array}{c}\text { Urine volume } \\
(\mathbf{m l} / \mathbf{k g})\end{array}$ & $\begin{array}{c}\text { Specific } \\
\text { gravity }\end{array}$ & Glucose & Blood & Urobilinogen \\
\hline $\begin{array}{c}\text { Rabbits } \\
(\mathrm{n}: \text { 42) }\end{array}$ & $8.25 \pm 0.37$ & $126.5 \pm 6.17$ & $1009 \pm 13.59$ & Negative & Negative & Negative \\
\hline
\end{tabular}

Values were shown as a mean \pm standard deviation.

results including $\mathrm{pH}$, urine volume, specific gravity, glucose, blood and urobilinogen were shown in Table 2. The qualitative echogenicity evaluation for observer 1 can be summarised as isoechoic (36/42) and hyperechoic (6/42), while for observer 2 it can be summarised as isoechoic (35/42) and hyperechoic (7/42). Quantitatively the mean pixel intensity analysed for the renal cortex was 59.2 \pm 2.23 (range: $28-91$ ).

Histopathologically, the renal cortex and medulla were examined. Sections were evaluated for existence of any degeneration, necrosis and inflammatory reactions. Tubule epithelium was found to have normal morphology in the cortex and medulla. In the examination of glomeruli, it was seen that bowman cavity and mesangium had normal morphology and no pathology was found. With these findings, it was determined that the kidney had normal histology and no pathological findings.

\section{Discussion and Conclusion}

The kind of histogram used in the present study offers a graphical representation of the values of the pixels in an image. It is more commonly referred to as an image histogram or a grey-level histogram. An image histogram shows the detection of the pixels at each point in a scene as well as the number of those pixels. Hence, various information related to the image can be extracted from the histogram. It is not possible to determine exactly where the pixels are located on an image. However, general information regarding the image can be obtained from its light-dark region values (1).

Dimitrov (5) claims that the heterogeneous renal echogenicity indicated hyperechoic findings in rabbits. However, qualitative observations may vary from person to person. Indeed, Ivancić and Mai (7) report that qualitative renal cortex to hepatic parenchymal echogenicity shows differences between observers. Renal calcinosis cases suspected of having mild renal insufficiency can be diagnosed histologically, although they cannot be diagnosed using radiographs (17). These facts reinforce the notion that qualitative results should always be verified with quantitative methods. Considering this case qualitative review of this study was evaluated by two observers and additionally images were analysed quantitatively.

Liu et al. (9) report that contrast-enhanced renal echogenicity increases the mean pixel intensity in rabbits. In the present study, the mean pixel intensity is $59.2 \pm 2.23$ (range: 28-91). However, we did not use contrast agents to measure the echogenicity, since clinicians typically do not use contrast agents to diagnose renal diseases. Ivancić and Mai (7) sought to investigate the kidney cortex in dogs using B-mode imaging. They report the mean pixel intensity to be 41 (95\% CI 38-44) for dogs. Maurya et al. (11) report the renal cortex structure to be significantly different in all experimental animals, including dogs and rabbits. This difference may stem from the histological structural diversity of the animals.

In children with a hydronephrosis renal echogenicity correlates with decreased renal function, and the results of the first postnatal ultrasound may use as a predictor of impaired relative renal function (3). Histopathological and ultrasound examinations of the kidney show that increased echogenicity significantly correlates to histopathological examination of some diseases as glomerulosclerosis, glomerular crescents, tubular atrophy and interstitial fibrosis. (2, 4, 12, 13, 22-24).

The quantitative evaluation of renal cortical echogenicity is not a commonly used approach, having only previously been described in humans $(10,20)$. An ultrasound-guided biopsy of the kidney can be performed to allow for a histological evaluation and a definitive diagnosis. However, it is an invasive method that clinicians do not commonly use. A histogram analysis using ultrasound images can be more appropriate and safer in the serial evaluation of tissues to monitor disease progression or the effectiveness of treatment (15). Such an 
appropriate has been recommended for the early diagnosis of certain renal diseases, for example, aminoglycosideinduced nephrotoxicity, and it has been reported to be more sensitive than the visual examination of ultrasound images during the early stages of the disease (18).

It is important to recognise that quantitative ultrasonography is not without difficulties. It has been suggested that echogenicity is not affected by the probe frequency or the type of device, but rather that it varies inversely to the gain (10). However, in this study the gain and all settings was found to be standard for all the rabbits. Additionally, the depth of the ROI is an important factor when performing the analysis. The strength of the returning echoes decreases as the depth and distance from the transducer increase. An ROI drawn deep within the tissue may not offer sufficient echogenicity data for analysis. The type and the amount of the tissue overlying the ROI also affect the echogenicity data $(8,20)$. None of our rabbits were obese, so the amount of subcutaneous tissue between the kidneys was only minimal.

Clinically, it is the subjective assessment of echogenicity that is used to make decisions. But the plentiful amount of fat vacuoles in the tubular epithelium of the renal cortex can affect qualitative echogenicity in normal kidney (25). This fact reinforces the notion that qualitative results should always be verified with quantitative methods.

We performed a histogram analysis of the rabbits' renal echogenicity both quantitatively and qualitatively. The results of this study could be used to perform a qualitative assessment and analysis of digitised renal cortical ultrasonographic images obtained from rabbits using the histogram technique, which could be used to quantitatively determine the echogenicity. We consider that a histogram analysis of the renal cortex may make a valuable contribution to the evaluation of the integrity of renal diseases. Additionally, we highlight the value of identifying a non-invasive method for diagnosing the progression of kidney disease in rabbits. In the future, clinicians may compare the quantitative results of this study with kidney disease histogram analysis results in rabbits.

\section{Acknowledgements}

A part of this study was presented as an oral presentation on $\mathrm{XXX}^{\text {th }}$ Congress of the European Association of Veterinary Anatomists Cluj Napoca, Romania, July 23-26, 2014.

\section{Financial Support}

This research received no grant from any funding agency or sector.

\section{Ethical Statement}

This study was approved by the Ethics Commission of the Mehmet Akif Ersoy University (93773921-194972).

\section{Conflict of Interest}

The authors declared that there is no conflict of interest.

\section{References}

1. Aktan S (2004): Digital Image Analysis in Livestock. 160165. In: Proocedings of $4^{\text {th }}$ National Livestock Science Congress, Isparta, Turkey.

2. Alm-Eldeen A, Tousson E (2012): Deterioration of glomerular endothelial surface layer and the alteration in the renal function after a growth promoter boldenone injection in rabbits. Hum Exp Toxicol, 31, 465-472.

3. Chi T, Feldstein VA, Nguyen HT (2006): Increased echogenicity as a predictor of poor renal function in children with grade 3 to 4 hydronephrosis. J Urol, 175, 1898-1901.

4. Demir A, Türker P, Bozkurt $\mathbf{S U}$, et al (2015): The histomorphological findings of kidneys after application of high dose and high-energy shock wave lithotripsy. Cent European J Urol, 68, 72-78.

5. Dimitrov RS (2012): Ultrasound features of kidneys in the rabbit (Oryctolagus Cuniculus). Vet World, 5, 274-278.

6. Drost WT, Henry GA, Meinkoth JH, et al (2000): Quantification of hepatic and renal cortical echogenicity in clinically normal cats. Am J Vet Res, 61, 1016-1020.

7. Ivancić M, Mai W (2008): Qualitative and quantitative comparison of renal vs. hepatic ultrasonographic intensity in healthy dogs. Vet Radiol Ultrasound, 49, 368-373.

8. Lamont AC, Pelmore JM, Thompson JR, et al (1995): Ultrasound assessment of liver and kidney brightness in infants. Use of the gray-level histogram. Invest Radiol, 30, 232-238.

9. Liu P, Gao YH, Tan KB, et al (2004): Grey scale enhancement of rabbit liver and kidney by intravenous injection of a new lipid-coated ultrasound contrast agent. World J Gastroenterol, 10, 2369-2372.

10. Manley JA, O'Neill WC (2001): How echogenic is echogenic? Quantitative acoustics of the renal cortex. Am J Kidney Dis, 37, 706-711.

11. Maurya H, Kumar T, Kumar S, et al (2018): Anatomical and physiological similarities of kidney in different experimental animals used for basic studies. J Clin Exp Nephrol, 3, 1-6.

12. Marian AJ, Yun W, Do-Sun Lim, et al (1999): $A$ transgenic rabbit model for human hypertrophic cardiomyopathy. J Clin Invest, 104, 1683-1692.

13. Moghazi S, Jones E, Schroepple J, et al (2005): Correlation of renal histopathology with sonographic findings. Kidney Int, 67, 1515-20.

14. Nakamura K, Sasaki N, Yoshikawa M, et al (2009): Quantitative contrast-enhanced ultrasonography of canine spleen. Vet Radiol Ultrasound, 50, 104-108.

15. Newell SM, Selcer BA, Girard E, et al (1998): Correlations between ultrosonographic findings and 
specific hepatic diseases in cats: 72 cases (1985-1997). J Am Vet Med Assoc, 213, 94-98.

16. Quesenberry K, Carpenter C (2012): Disorders of the Reproductive and Urinary Systems. 217-231. In: E Klapheke, J Paul-Murphy (Eds), Ferrets, Rabbits, and Rodents. Elsevier Press, USA.

17. Redrobe S (2013): Ultrasonography. 190-211. In: F Harcourt-Brown, J Chitty (Eds), Rabbit Surgery, Dentistry and Imaging. British Small Animal Veterinary Association, England.

18. Rivers BJ, Walter PA, Holm JC, et al (1996): Gray-scale sonographic characterization of aminoglycoside-induced nephrotoxicosis in a canine model. Invest Radiol, 31, 639651.

19. Smith-Levitin M, Blickstein I, Albrect-Shach AA et al (1997): Quantitative assessment of gray-level perception: observers' accuracy is dependent on density differences. Ultrasound Obstet Gynecol, 10, 346-349.

20. Nyland TG, Mattoon JS, Wisner ER (1995): Physical Principles, Instrumentation, and Safety of Diagnostic
Ultrasound. 3-18. In: TG Nyland, JS Mattoon (Eds), Veterinary Diagnostic Ultrasound. WB Saunders Co, Philadelphia.

21. Robinson DE, Gill RW, Kossoff G (1986): Quantitative sonography. Ultrasound Med Biol, 12, 555-565.

22. Song CY, Kim BC, Hong HK, et al (2007): TGF-beta type II receptor deficiency prevents renal injury via decrease in ERK activity in crescentic glomerulonephritis. Kidney Int, 71, 882-888.

23. Walter PA, Johnston GR, Feeney DA et al (1988): Applications of ultrasonography in the diagnosis of parenchymal kidney disease in cats: 24 cases (1981-1986). J Am Vet Med Assoc, 192, 92-98.

24. Yabuki A, Endo Y, Sakamoto H, et al (2008): Quantitative assessment of renal cortical echogenicity in clinically normal cats. Anat Histol Embryol, 37, 383-386.

25. Yeager AE, Anderson WI (1989): Study of association between histologic features and echogenicity of architecturally normal cat kidneys. Am J Vet Res, 50, 860863. 